\title{
Pengaruh Kepercayaan dan Kualitas Pelayanan Terhadap Kepuasan Konsumen Pada Hotel Bukit Serelo Lahat
}

\author{
Kasinem \\ Sekolah Tinggi Ilmu Ekonomi Serelo Lahat, Kasinem.stie@gmail.com
}

\begin{abstract}
ABSTRAK
Penelitian ini bertujuan untuk mengetahui Pengaruh Kepercayaan dan Kualitas terhadap Kepuasan Konsumen pada Hotel Bukit Serelo Lahat.Jumlah sampel yg digunakan dalam penelitian adalah 46 orang pelanggan Hotel Serelo Lahat.Metode analisa yang digunakan dalam penelitian ini adalah kualitatif dan analisa kuantitatif. Hasil pengujian statistik dapat diambil kesimpulan Kepercayaan dan Kualitas Pelayanan mempunyai pengaruh yang positif dan negatif terhadap Kepuasan Konsumen. Hasil uji anova variabel independent yang meliputi Kepercayaan (X1) dan Kualitas Pelayanan (X2) secara simultan berpengaruh positif dan signifikan terhadap Kepuasan Pelanggan. Dari hasil uji parsial bahwa diketahui nilai koefesien regresi variabel Kualitas Pelayanan (X2) adalah sebesar $0,588$ berpengaruh negatif terhadap Kepuasan Pelanggan( $\mathrm{Y})$, Dari hasil keseluruhan menujukan bahwa Kepercayan berpengaruh signifikan terhadap Kepuasan Konsumen, dan Kualitas Pelayanan tidak berpengaruh signifikan terhadap Kepuasan Konsumen, daat juga dilihat bahwa Kepercayaan dan Kualitas Pelayanan berpengaruh signifikan secara bersama-sama terhadap Kepuasan Konsumen.
\end{abstract}

Kata Kunci : Kepercaayaan, Kualitas Pelayanan, Kepuasan Pelanggan.

\section{ABSTRACT}

This study aims to determine the effect of trust and quality on customer satisfaction at Hotel Bukit Serelo Lahat. The number of samples used in the study were 46 customers at Hotel Serelo Lahat. The analysis methods used in this study are qualitative and quantitative analysis. The results of statistical testing can be taken. Conclusion Trust and Service Quality have a positive and negative influence on Customer Satisfaction. The independent variable ANOVA test results which include Trust (X1) and Service Quality (X2) simultaneously have a positive and significant effect on Customer Satisfaction. From the partial test results, it is known that the regression coefficient value of the Service Quality variable (X2) is -0.588 has a negative effect on Customer Satisfaction (Y). It can also be seen that Trust and Service Quality simultaneously have a significant effect on Consumer Satisfaction.

Keywords: Trust, Service Quality, Customer Satisfaction.

\section{A. PENDAHULUAN}

Salah satu syarat agar Hotel menjadi sukses dalam persaingan di masa depan adalah berusaha mencapai tujuan dengan menciptakan dan mempertahankan pelanggan. Peranan hotel sebagai sarana dalam memenuhi kebutuhan pelanggan menjadi semakin penting bagi masyarakat. Peneliti menganalisis tingkat kepuasan pelanggan terhadap kualitas pelayanan pada Hotel Bukit Serelo dan mengetahui faktor-faktor yang mempengaruhi tingkat kepuasan pelanggan.

Dewasa ini, pemasaran suatu perusahaan tidak hanya dinilai dari seberapa banyak konsumen yang berhasil diperoleh, namun juga bagaimana cara mempertahakankan konsumen tersebut. Rasa puas dan tidak puas konsumen terletak pada hubungan antara harapan 
konsumen dengan prestasi yang diterima dari barang atau jasa.

Apabila pihak perusahaan tersebut mampu memberikan kepuasan bagi pelanggan, maka hal itu akan berdampak pada tingkat kepercayaan dan kualitas pelayanan. Untuk meningkatkan kepuasan konsumen, perusahaan tersebut perlu mengatur strategi pemasaran agar konsumen tertarik terhadap produk-produk yang ditawarkan.Strategi tersebut salah satunya dengan memperkirakan kecenderungan permintaan konsumen terhadap suatu jasa.Kepuasan konsumen merupakan aspek penting yang mempengaruhi kepercayaan dan kualitas pelayanan.

Kepercayaan juga berkaitan dengan kepuasan konsumen, semakin tinggi kepercayaan konsumen maka semakin tinggi kepuasan konsumen. Informasi yang baik akan menumbuhkan kepercayaan konsumen terhadap suatu produk maupun layanan jasa, hal inidikarenakan pengalaman yang terbentuk pada memori konsumen terhadap suatu jasa dapat membantu rasa percaya seseorang. Dalam hal ini unsur kepercayaan menjadi faktor kunci bagi perusahaan untuk memenangkan persaingan, begitu juga sebaliknya.Bisnis jasa perhotelan merupakan bisnis jasa yang berdasarkan asas kepercayaan yang didukung dengan kepercayaan dan kualitas pelayanan, sehingga masalah rasa percaya dan kualitas pelayanan pelanggan menjadi faktor yang sangat menentukan keberhasilan bisnis ini.

Pelayanan yang berkualitas dapat menarik minat konsumen untuk menginap. Hal terpenting bagi pihak manajemen Hotel Bukit Serelo adalah mengetahui dan memahami kriteria penentu jasa yang mempengaruhi Keputusan tamu hotel untuk dapat membantu mereka dalam mempertahankan, memelihara, dan meningkatkan kualitas jasa yang sudah ada.

Hal ini menunjukkan bahwa Hotel Bukit Serelo melakukan analisa terhadap faktor penentu Kepercayaan dan Kualitas Pelayanan yang mempengaruhi kepuasan pelanggan. Apabila Pelanggan kurang percaya dan kualitas kurang memadai tentu hotel akan kehilangan pelanggan, untuk mengetahui seberapa tingkat kepercayaan konsumen dan seberapa puas konsumen mengenai kualitas pelayanan hotel.

\section{B. KAJIAN TEORI \\ $>$ Kepuasan Konsumen}

$$
\text { Menurut Kotler }
$$

Kepuasan adalah perasaan senan atau kecewa seorang yang timbul karena membandingkan kinerja yang dipersepsikan produk (atau hasil) terhadap ekspetasi mereka . sedangkan ketidakpuasan timbul apabila hasil yang di peroleh tidak memenuhi harapan konsumen.

Menurut Tjiptono (2010:150) menyatakan bahwa :"Kepuasan atau Ketidakpuasan konsumen adalah respon konsumen terhadap evolusi ketidaksesuaian / diskomfirmasi yang dirasakan antara harapan sebelumnya (atau norma kinerja lainya) dankinerja aktual produk yang di rasakan setelah pemakaiannya".

Beberapa pengukuran kepuasan konsumen mempunyai tiga bentuk yang berbeda yaitu :

a. Positif disconfirmation, dimana kinerja lebih baik dari harapan.

b. Simple Confirmation ,dimana kinerja sama dengan harapan.

c. Negara disconfirmation ,dimana kierja lebih baik buruk dari harapan.

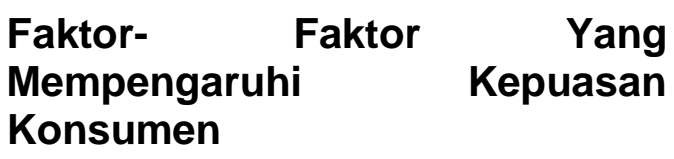


Menurut Tri Ratnasari (2011:17-8) ada lima faktor yang mempengaruhi kepuasan pelanggan.

a. Kualitas Produk

Pelanggan akan merasa puas bila hasil evaluasi mereka menunjukan bahwa produk yang mereka gunakan bekualitas.

b. Harga

Produk yang berkualitas yang sama dengan produk jasa lain, tetapi di tetapkan dengan harga yang lebih murah akan memberikan nilai yang lebih tinggi terhadap pelanggannya.

c. Kualitas Pelayanan

Pada industri ,adalah mutlak bahwa pelanggan akan merasa puas apabila merak a mendapatkan pelayanan yang baik atau sesuai dengan apa yang di harapkan.

d. Emosional (Kepercayaan)

Pelanggan akan merasa bangga dan mendapatkan keyakinan bahwa orang lain akan kagum terhadap dia bila menggunakan produk dengan merk tertentu, sehingga membuatnya mengalami tingkat kepuasan yang tinngi. Kepuasan yang di peroleh bukan dari produk, akan tetapi nilai sosial yang membuat pelanggan menjadi puas terhadap merk tertentu.

e. Biaya

Pelanggan tidak r perlu
mengeluarkan biaya tambahan
atau tidak membuang waktu untuk
mendapatkan
produk/jasa.Cenderung puas pada
produk/jasa.

$>\quad$ Indikator Kepuasan Konsumen

Hawkins dan Lonney dikutip dalam Tjiptono (2010:101) indikator kepuasan pelanggan terdiri dari ?

a. Kesesuaiaan harapan

Merupakan tingkat kesesuaian antara kinerja produk yang diharapkan oleh pelanggan dengan yang di rasakan oleh pelanggan, meliputi :

- Produk yang diperoleh sesuai atau melebihi dengan yang diharapkan.

- Pelayanan oleh karyawan yang diperoleh sesuai atau melebihi dengan yang di harapkan.

- Fasilitas penunjang yang didapat sesuai atau melebihi yang diharapkan

b. Minat Berkunjung Kembali

Merupakan kesediaan untuk berkunjung kembali atau melakukan pembelian ulang pada produk terkait, meliputi ?

- Berminat untuk berkunjung kembali karena pelayanan yang di berikan oleh karyawan memuasakan.

- Berminat untuk berkunjung kembali karna nilai dan manfaat yang diperoleh setelah mengkonsumsi produk.

- Berminat untuk berkunjung kembali karena fasilitas menunjang yang disediakan memadai.

c. Kesediaan Merekomendasikan Merupakan kesediaan pelanggan untuk merekomendasikan produk yang telah dirasakannya kepada teman atau keluarga, me;iputi :

- Menyarankan temann atau kerabat untuk membeli ptoduk yang ditawarkan karena pelayanan yang memuaskan.

- Menyarankan teman atau kerabat untuk membeli produk yang ditawarkan karena fasilitas menunjang yang disediakan memadai.

- Menyarankan teman atau kerabat untuk membeli produk yang ditawarkan karena nilai atau manfat yang didapat setelah mengkonsumsi sebuah produk jasa. 


\section{$>$ Kepercayaan}

Kepercayaan mempunyai banyak pengertian, berikut ini definisi-definisi kepercayaan pelanggan menurut beberapa ahli:

Luthfi (2011:59) "kepercayaan adalah sebagai kesediaan untuk bergantung kepada pihak lain yang telah dipercaya". Dari definisi di atas. Kepercayaan merupakan variabel terpenting dalam membangun sebuah hubungan jangka panjang atara satub pihak dengan pihak lainnya.

Kepercayaan tersebut sering disebut sebagai object attribute linkages yaitu kepercayaan konsumen tentang kemungkinan adanya hubungan antara sebuah objek dengan atributya yang relevan. Kepercayaan (trust), kepercayaan timbul dari suatu proses yang lama sampai kedua belah pihak saling mempercayai. Apabila kepercayaan sudah terjalin di antara pelanggan dan perusahaan, maka usaha untuk membinanya akan lebih mudah, hubungan perusahaan dan pelanggan tercermin dari tingkat kepercayaan (trust) para pelanggan.

\section{Faktor-Faktor}

Mempengaruhi Kepercayaan

Adapun Lutfi (2011 :59)faktor-faktor yang mempengaruhi kepercayaan konsumen terhadap perusahaan adalah sebagai berikut:

1. Pengalaman ( Experienced) dengan pekerjaan yang dilakukan oleh perusahaan, mengenai bisnis dan prestasi perusahaan dalam bidang perekonomian dan lain sebagainya. Pengalaman yang banyak dan menarik dalam bisnis, akan memebuat perusahaan lebih memahami keinginan dan kebutuhan pelanggan.

2. Kualitas Kerja
Kualitas kerja adalah proses dan hasil kerja perusahaan yang dapat dinilai oleh sebagai pelanggan atau masyarakat. Kualitas kerja yang tidak terbatas akan menghasilkan kepercayaan yang berkut.

3. Kecerdasan

Kemampuan perusahaan dalam mengolah masalah yang terjadi dalam perusahaan. Kecerdasan juga dapat membangun kepercayaan, karena kredibilitas yang tinggi tanpa didasari oleh kecerdasan dalam menarik pelanggan tidak mampu meningkatkan kepercayaan pelanggan.

\section{$>$ Indikator Kepercayaan}

Gefen (dalam Yee dan faziharudean,2010) menyatakan bahwa indikator kepercayaan terdiri dari 3 komponen, yaitu:

1. Integritas (Integrity)

Merupakan persepsi konsumen bahwa perusahaan mengikuti prinsip-prinsip yang dapat diterima seperti menepati janji, berperilaku sesuai etika dan jujur. Integritas perusahaan tergantung dari konsistensi perusahaan dimasa lalu, komunikasi kredibel atau komunikasi tidak kredibel suatu perusahaan pada kelompok lain, dan apakah tindakan yang dilakukan perusahaan sesuai dengan janji atau kata-kata yang diucapkan perusahaan.

2. Kebaikan (Benevolence)

Yang didasarkan pada besarnya kepercayaan kemitraan yang memiliki tujuan dan motivasi yang menjadi kelebihan untuk organisasi lain pada saat kondisi yang baru muncul, yaitu kondisi dimana komitmen tidak terbentuk.disitula karyawan mempunyai kebaikan untuk membantu 


\section{Kompetensi (Competence)}

Kompetensi

merupakan

kemampuan untuk memecahkan permasalahan yang dihadapi oleh konsumen dan memenuhi segala keperluannya.

Kemampuan mengacu pada keahlian dan karakteristik yang memungkinkan suatu kelompok mempunyai pengaruh yang dominan.

Berdasarkan uraian diatas, maka indikator dalam penelitian ini yaitu integritas (integrity), kebaikan (benevolence), kompetensi (competence).Indikator tersebut diapakai karena dianggap sesuai dengan penelitian ini.

\section{$>$ Kualitas Pelayanan}

Kualitas pelayanan mempunyai banyak pengertian, berikut definisidefinisi kualitas pelayanan menurut beberapa ahli:

Menurut Tjiptono dan Chandra (2011:164) "kualitas pelayanan adalah kondisi dinamis yang berhubungan dengan produk, jasa, sumber daya manusia, proses, dan lingkungan yang memenuhi atau melebihi harapan".

Kualitas pelayanan melalui kinerja merupakan faktor penentu kepuasan masyarakat, artinya apabila semakin baik kualitas pelayanan dengan melalui kinerja untuk meningkatkan kepuasan masyarakat pada angkutan umum (transmusi) tentunya masyarakat merasakan puas serta menumbuhkan rasa percaya atas pelayanan melalui kinerja tersebut. (Oktariansyah, dkk 2017:51)

Berbagai definisi telah diuraikan diatas maka kualitas pelayanan menurut penulis yaitu segala bentuk penyelenggaraan pelayanan secara maksimal yang diberikan perusahaan dengan segala keunggulan dalam rangka memenuhi kebutuhan pelanggan demi memenuhi harapan pelanggan.

\section{$>$ Dimensi Kualitas Pelayanan}

Dalam suatu kualitas jasa terdapat dimensi-dimensi yang menjadi tolak ukur dari kualitas suatu jasa. Menurut Parasuraman, Zeithaml, dan Berry (1988) dalam buku Tjiptono \& Chandra (2011:115) menyatakan bahwa terdapat lima dimensi utama pada kualitas pelayanan, antara lain :

1. Tangibles/ Nyata (bukti langsung), yang meliputi fasilitas fisik dari jasa, perlengkapan atau peralatan yang dipergunakan, pegawai dan sarana komunikasi atau representasi fisik dari jasa misalnya peralatan yang dipakai untuk mengkonsumsi jasa tersebut, contoh sambungan telepon.

2. Reliability (kehandalan), yaitu kemampuan memberikan pelayanan yang dijanjikan dengan segera, akurat dan memuaskan. .

3. Responsiveness (daya tanggap), yaitu keinginan para staf untuk membantu para pelanggan dan memberikan pelayanan dengan tanggap, yang meliputi kecepatan, kompetensi, kenyamanan, mudah direparasi, serta penanganan keluhan yang memuaskan sejak proses penjualan hingga purna jualnya (serviceability).

4. Assurance (jaminan), mencakup pengetahuan, kemampuan, kesopanan dan sifat dapat $d$ ipercaya yang dimiliki para staf perusahaan, bebas dari bahaya, resiko atau keragu-raguan, termasuk kualitas jasa yang dipersepsikan oleh pelanggan dari citra dan reputasi produk serta tanggung jawab perusahaan terhadapnya (perceived quality).

5. Emphaty (empati), meliputi kemudahan dalam melakukan hubungan, komunikasi yang baik, perhatian dari perusahaan kepada pribadi pelanggan dan memahami kebutuhan para pelanggan. 
Semakin tingginya tingkat persaingan, akan menyebabkan pelanggan menghadapi lebih banyak alternative pilihan layanan jasa perhotelan, dari harga, dan kualitas. Pelanggan akan mencari nilai yang di anggap tinggi dan baik. Kualitas yang rendah akan menimbulkan ketidakpuasan para pelanggan.

\section{$>$ Faktor Penentu Kualitas Pelayanan}

Lima faktor dominan atau penentu kualitas pelayanan jasa menurut Tjiptono (2014:282), yaitu:

- $\quad$ Berwujud (Tangible), yaitu berupa penampilan fisik, peralatan dan berbagai materi yang terlihat yang dapat dinilai baik.

- $\quad$ Empati (Emphaty), yaitu kesediaan karyawan dalam menjalin relasi, komunikasi yang baik, perhatian pribadi dan pemahaman atas kebutuhan individual pelanggan.

- Daya tanggap (Responsiveness), yaitu kemauan dan kemampuan dari karyawan memberikan pelayanan secara cepat dan tanggap. Kesigapan para karyawan untuk memenuhi keinginan konsumen dengan tanggap dan ramah.

- Keandalan (Reliability), yaitu kemampuan untuk memberikan layanan dengan segera, akurat, konsisten dan memuaskan.

- Jaminan (Assurance), yaitu mencakup pengetahuan, kompetensi, kesopanan dan sifat dapat dipercaya yang dimiliki para staff mengenai janji yang diberikan, bebas dari bahaya, resiko atau keragu-raguan.

Komitmen merupakan komponen yang dapat membangun relationship dan merupakan hal yang mudah hilang.
Yang akan dibentuk hanya dengan pihak - pihak yang saling percaya.

\section{METODE PENELITIAN}

Dalam Penelitian ini peneliti menggunakan jenis penelitian asosiatif yaitu penelitian yang bertujuan mengetahui hubungan antara tiga variabel atau lebih (Sugiyono, 2010:69).Dalam penelitian ini tiga variabel yang dimaksud adalah variabel X1 (Kepercayaan) variabel X2 (Kualitas Pelayanan) dan variabel $Y$ (Kepuasan Konsumen) pada Hotel Bukit Serelo Lahat.

Pada penelitian ini, peneliti menghadapi kasus dimana jumlah populasi yang ada sangat banyak dan sulit diketahui dan tidak diketahui jumlah sampelnya, sehingga peneliti memilih metode pengambilan sampel yang akan digunakan adalah metode Non Probability Sampling, yaitu teknik pengambilan sampel yang tidak memberi peluang atau kesempatan yag sama bagi setiap unsur (anggota) populasi untuk dipilih menjadi anggota sampel ( Sugiyono : 2011).

Dalam menentukan jumlah sampel digunakan pengambilan sampel dengan menggunakan teknik rumus Slovin,yaitu:

Keterangan :

$$
n=\frac{N}{1+N e^{2}}
$$

$\mathrm{n}=$ Ukuran Sampel

$\mathrm{N}=$ Ukuran Populasi

$1=$ Konstanta

$\mathrm{e}=$ Batas toleransi kesalahan ( error tolerance ) misalnya $10 \%$

Berdasarkan rumus diatas, maka dapat dihitung besarnya sampel dari jumlah populasi yag ada yaitu sebagai berikut : $n=\frac{290}{1+290(0,1)^{2}}=48.97 \rightarrow 49$ sampel

Berdasarkan Perhitungan di atas, maka ukuran sampel minimal dalam penelitian ini ditetapkan dengan á $=0,05$ (derajat 
kepercayaan 95\%) maka diperoleh ukurab sampel (n) minimal sebesar 76 , maka pada penelitian ini ditentukan sampel yang berjumlah 49 sampe konsumen yang menngunakan jasa Hotel Bukit Serelo Lahat.

Adapun tahap - tahap dari pengambilan data primer adalah sebagai berikut :

a. Study Pustaka ( Library Research ) Yaitu penelitian yang dilakukan dengan membaca literature yang relevan dengan permasalahan yang teliti untk mendapatkan landasan teori, menurut Arikunto (2013:37)

b. Study Lapangan ( Dield research) Yaitu suatu metode pengumpulan data untuk mendapatkan data primer dengan cara melakukan pengamatan langsung terhadap objek pnelitian, menurut Arikunto (2013:38), dengan teknik pengumpulan data sebagai berikut : Observasi, Wawancara, kuisioner.

Metode analisis data

1. Uji Instrumen

Uji Instrumen yang digunakan dalam penelitian ini adalah uji validitas data dan uji vareabel.

2. Uji Statistik Infrensial

Menggunakan analisisRegresi

Linier Berganda, koefesien determinasi, uji t dan uji f.

\section{HASIL DAN PEMBAHASAN Uji Instrumen}

Hasil penelitian berdasarkan Uji instrument data menunjukan :

\section{Pengujian Validitas}

Ketiga variabel kepercayaan, kualitas pelayanan, dan kepuasan pelanggan menunjukkan Nilai $r$ tabel untuk sampel pada taraf signifikan 5\% adalah 0,282. Tabel hasil uji validitas menunjukkan bahwa semua butir pertanyaan 1 sampai 10 adalah valid, karena nilai $r_{x y}>0,282$.

\section{Pengujian Reliabilitas}

Menunjukkan bahwa nilai alpha cronbach's variabel kepercayaan $\left(\mathrm{X}_{1}\right)$, Kualitas pelayanan $\left(X_{2}\right)$ dan kepuasan pelanggan $(Y)$ yang diperoleh lebih besar dari 0,60, maka dapat disimpulkan bahwa instrumen untuk variabel kepercayaan, kualitas pelayanan adalah reliabel atau terpercaya.

\section{Analisis Statistik}

a. Analisis Regresi linier berganda hasil Persamaan Regresi Linier Berganda dapat dilihat pada tabel berikut

\section{Tabel Hasil Uji Regresi Liniear Berganda}

\begin{tabular}{|c|c|c|c|c|c|c|}
\hline & \multirow[b]{2}{*}{ Model } & \multicolumn{2}{|c|}{$\begin{array}{l}\text { Unstandardized } \\
\text { Coefficients }\end{array}$} & \multirow{2}{*}{$\begin{array}{c}\text { Standardized } \\
\text { Coefficients } \\
\text { Beta } \\
\end{array}$} & \multirow[b]{2}{*}{$\mathrm{t}$} & \multirow[b]{2}{*}{ Sig } \\
\hline & & B & Std. Error & & & \\
\hline \multirow[t]{3}{*}{1} & (Constant) & 45.795 & 11.853 & & 3.864 & .000 \\
\hline & $\mathrm{x} 1$ & .143 & 191 & 141 & .005 & .000 \\
\hline & $x 2$ & -.069 & .158 & -.066 & .439 & .000 \\
\hline
\end{tabular}

Persamaan regresi yang didapat adalah:

$Y=45.795+0,143 \times 1-0,69 \times 2$
Berdasarkan persamaan diatas maka dapat diuraikan sebagai berikut :

1. Kepercayaan berpengaruh positif terhadap Kepuasan Konsumen dengan koefesien regresi sebesar 
0,143 tanda + (positif) pada variabel kepercayaan menujukan hubungan yang searah, artinya bila kepercayaan ditingkatkan maka akan berpengaruh terhadap Kepuasan Konsumen pada Hotel Bukit Serelo.

2. Kualitas Pelayanan berpengaruh negatif terhadap kepuasan konsumen dengan koefesien regresi sebesar -0,091 tanda (negatif) pada variabel kualitas pelayanan menunjukan hubungan yang tidak searah, artinya apabila usaha kualialitas pelayanan tidak ditingkatkan maka berpengaruh terhadap Kepuasan Konsumen Hotel Bukit Serelo.

3. Kepercayaan dan Kualitas Pelayanan mempunyai pengaruh yang postif dan negatif terhadap Kepuasan Konsumen.

a. Koefesien Determinasi

Koefesien determinasi mengukur seberapa besar pengaruh variabel independen secara keseluruhan

\section{Tabel Uji Koefesien Determinasi} Model Summary

\begin{tabular}{|l|c|l|l|l|}
\hline Model & $\mathrm{R}$ & $\begin{array}{c}\mathrm{R} \\
\text { Square }\end{array}$ & $\begin{array}{c}\text { Adjusted } \mathrm{R} \\
\text { Square }\end{array}$ & $\begin{array}{l}\text { Std. Error of } \\
\text { the Estimate }\end{array}$ \\
\hline 1 & $.154^{\mathrm{a}}$ & .424 & -414 & 1.708 \\
\hline
\end{tabular}

a. Predictors: (Constant), kualitas_pelayanan $\mathrm{X}_{2}$, kepercayaan $\mathrm{X}_{1}$

Dari tabel diatas maka diketahui $\mathrm{R}^{2}$ adalah 0,424 . Dari nilai tersebut dapat dilihat bahwa Kepuasan Konsumen dipengaruhi oleh Kepercayaan dan Kualitas Pelayanan sebesar 0,424. Hal ini berarti Kepercayaan mempengaruhi Kualitas Pelayanan sebesar $42,40 \%$ dan sisanya $57.60 \%$ dipengaruhi faktor lain.

b. Uji Simultan (Uji F)
Pada Uji F dgunakan untuk mengetahui signifikan variabel Kepercayaan (X1) dan Kualitas Pelayanan (X2) terhadap Kepuasan Konsumen

Dengan Kriteria Uji sebagai berikut: Ho diterima apabila : $\mathrm{F}$ hitung $\leq$ Ftabel pada $\alpha=5 \%$

Ho diterima apabila : F hitung $\geq F$ tabel $\alpha=5 \%$

Tabel Hasil Uji Signifikasi Simulltan (Uji F)

\begin{tabular}{|c|c|c|c|c|c|c|}
\hline \multicolumn{7}{|c|}{ ANOVA $^{b}$} \\
\hline \multicolumn{2}{|c|}{ Model } & Sum of Squares & Df & $\begin{array}{l}\text { Mean } \\
\text { Square }\end{array}$ & $F$ & Sig. \\
\hline \multirow[t]{3}{*}{1} & Regression & 3.280 & 2 & 1.640 & .562 &, $000^{a}$ \\
\hline & Residual & 134.271 & 46 & 2.919 & & \\
\hline & Total & 137.551 & 48 & & & \\
\hline
\end{tabular}

a. Predictors: (Constant), kualitas_pelayananX2, kepercayanX1 


\section{ANOVA $^{b}$}

\begin{tabular}{|ll|l|l|l|l|l|}
\hline \multicolumn{2}{|l|}{ Model } & Sum of Squares & Df & $\begin{array}{l}\text { Mean } \\
\text { Square }\end{array}$ & F & Sig. \\
\hline 1 & Regression & 3.280 & 2 & 1.640 & .562 &, $000^{\mathrm{a}}$ \\
& Residual & 134.271 & 46 & 2.919 & & \\
& Total & 137.551 & 48 & & & \\
\hline
\end{tabular}

b. Dependent Variable: epuasan_konsumenY

Hasil pengujian Anova dengan menggunakan Uji $F$ tabel di atas dapat dilihat $F$ hiung sebesar 0,562 dengan tingkat signifikasi 0,000 dan nilai Fhitung dibandingkain dengan nilai Ftabel 2,03 di dapat nilai Fhitung sebesar 0,562 jdi Fhitung lebih kecil dari Ftabel $(0,562<2,03)$ dengan nilai Sig
0,000 yang lebih kecil dari taraf signifikasi yang digunakan 0,05.

Kesimpulannya bahwa variabel independent yang meliputi Kepercayaan (X1) dan Kualitas Pelayanan (X2) secara simultan berpengaruh positif dan signifikan terhadap Kepuasan Pelanggan.

c. Uji Signifikasansi Parsial

Tabel Hasil Uji Signifikasi Parsial (Uji t X1 dengan Y)

\begin{tabular}{|c|c|c|c|c|c|c|}
\hline & & \multicolumn{2}{|c|}{$\begin{array}{l}\text { Unstandardized } \\
\text { Coefficients }\end{array}$} & $\begin{array}{l}\text { Standardized } \\
\text { Coefficients }\end{array}$ & \multirow[b]{2}{*}{$\mathrm{t}$} & \multirow[b]{2}{*}{ Sig. } \\
\hline \multicolumn{2}{|c|}{ Model } & $B$ & Std. Error & Beta & & \\
\hline \multirow[t]{2}{*}{1} & (Constant) & 40.530 & 8.620 & & 4.702 & .000 \\
\hline & kepercayanX1 & .143 & .149 & .141 & .960 & .342 \\
\hline
\end{tabular}

a. Dependent Variable kepuasan_konsumen Y

Dari tabel diatas diketahui nilai $t$ terhadap Kepuasan Pelanggan( $\mathrm{Y}$ ), hitung sebesar $-0,960<>$ Ttabel 2,011 berpengaruh positif bahwa semaki dan nilai signifian (Sig) $0,000>0,05$, menikatkan Kepercayaan (X1) maka variabel Kepercayaan (X1) adalah akan meningkat pula Kepuasan sebesar 0,960 berpengaruh positif Konsumen $(\mathrm{Y})$. 
Tabel Hasil Uji Signifikasi Parsial (Uji t X2 dengan Y)

\begin{tabular}{|c|c|c|c|c|c|}
\hline \multirow[b]{2}{*}{ Model } & \multicolumn{2}{|c|}{$\begin{array}{l}\text { Unstandardized } \\
\text { Coefficients }\end{array}$} & \multirow{2}{*}{$\begin{array}{l}\text { Standardized } \\
\text { Coefficients } \\
\text { Beta } \\
\end{array}$} & \multirow[b]{2}{*}{$\mathrm{t}$} & \multirow[b]{2}{*}{ Sig. } \\
\hline & B & Std. Error & & & \\
\hline (Constant) & 40.530 & 8.620 & & 4.702 & .000 \\
\hline kualitas_pelayananX2 & -.091 & .155 & -.087 & -.588 & 0.05 \\
\hline
\end{tabular}

a. Dependent Variable: epuasan_konsumenY

Dari tabel diatas diketahui nilai $T$ hitung sebesar $-0,588<>$ Ttabel 2,011 dan nilai signifian (Sig) $0,000>0,05$.

Variabel Kualitas Pelayanan (X2) adalah sebesar -0,588 berpengaruh negatif terhadap Kepuasan Pelanggan $(\mathrm{Y})$, berpengaruh negatip bahwa meningkatkan Kualitas Pelayanan (X2) tidak mempengaruhi Kepuasan Konsumen (Y).

\section{E. KESIMPULAN}

Sesuai dengan hasil analisis terhadap data penelitian, dapat diambil beberapa kesimpulan sebagai berikut :

1. $Y=45.795+0,143 X 1-0,69 X 2$

Kepercayaan berpengaruh positif terhadap Kepuasan Konsumen dengan koefesien regresi sebesar 0,143 tanda $+($ positif) pada variabel kepercayaan searah Konsumen Kualitas Pelayanan berpengaruh negatif terhadap kepuasan konsumen dengan koefesien regresi sebesar $-0,091$ tanda - ( negatif) pada variabel kualitas pelayanan menunjukan hubungan yang tidak searah.

2. Diketahui $\mathrm{R}^{2}$ adalah 0,424 . Dari nilai tersebut dapat dilihat bahwa Kepuasan Konsumen dipengaruhi oleh Kepercayaan dan Kualitas Pelayanan sebesar 0,424. Hal ini berarti Kepercayaan mempengaruhi Kualitas Pelayanan sebesar $42,40 \%$ dan sisanya $57.60 \%$ dipengaruhi faktor lain.
3. Hasil pengujian Anova dengan menggunakan $\mathrm{Uji}_{\mathrm{j}} \mathrm{F}$ tabel diatas dapat dilihat $F$ hitung sebesar 0,562 dengan tingkat signifikasi 0,000 dan nilai $F$ hitung dibandingkan dengan nilai Ftabel 2,03 di dapat nilai Fhitung sebesar 0,562 Fhitung lebih kecil dari Ftabel $(0,562<2,03)$ dengan nilai Sig 0,000 yang lebih kecil dari taraf signifikasi yang digunakan 0,05 .bahwa variabel independent yang meliputi Kepercayaan (X1) dan Kualitas Pelayanan (X2) secara simultan berpengaruh positif dan signifikan terhadap Kepuasan Pelanggan.

4. Uji Signifikansi Parsial (Uji t) menunjukan

Ho diterima jika $T$ sig $\geq 0,05$, Ho ditolak jika t sig $\leq 0,05$

Hasil dan pengambilan keputusan dalam Uji t Kualitas Pelayanan (X2) menunjukan diperoleh nilai T hitung sebesar - 0,588 <>Ttabel 2,011 dan nilai signifian (Sig) $0,000>$ 0,05 .

5. Dari hasil keseluruhan menujukan bahwa Kepercayan berpengaruh signifikan terhadap Kepuasan Konsumen, dan Kualitas Pelayanan tidak berpengaruh signifikan terhadap Kepuasan Konsumen, daat juga dilihat bahwa Kepercayaan dan Kualitas Pelayanan berpengaruh signifikan 
secara bersama-sama terhadap Kepuasan Konsumen.

\section{DAFTAR PUSTAKA}

Arikunto. 2013. Prosudur Penelitian: Suatu Pendekatan Praktek, Jakarta, Rineke cipta

Kotler, Phillip. 2013. Manajemen Pemasaran, Jilid 1 dan 2. PT. IndeksKelompok Gramedia. Jakarta

Kotler, Phillip. 2012, manajemen pemasaran, Erlangga, Jakarta

Kotler, Philip and Gary amstrong 2010 ,prinsip - prinsip pemasaran ,Universitas Diponegoro.
Oktariansyah, Damayanti, R, Usman, B \& Eko Putra, A. 2017. Analisis Kualitas Pelayanan Angkutan Umum (Transmusi) Melalui Kinerja Terhadap Kepuasan Masyarakat di Kota Palembang. Jurnal Manajemen dan Bisnis Sriwijaya Vol.15 (1), 2017, Hal: 49-61.

Sugiyono. 2011. Statika untuk penelitian, Penerbit Alpabeta, Bandung

Swasta, Basu 2011. manajemen pemasaran.PT BPE, Yogyakarta.

Tjiptono, Candra, 2011. Strategi Bisnis Pemasaran. Yogjakarta. 